\title{
Effects of technological distance on innovation performance under heterogeneous technological orientations
}

\author{
Citation for published version (APA):
}

Zhu, S., Hagedoorn, J., Zhang, S., \& Liu, F. (2021). Effects of technological distance on innovation performance under heterogeneous technological orientations. Technovation, 106, [102301]. https://doi.org/10.1016/j.technovation.2021.102301

Document status and date:

Published: 01/08/2021

DOI:

10.1016/j.technovation.2021.102301

Document Version:

Publisher's PDF, also known as Version of record

\section{Document license:}

Taverne

Please check the document version of this publication:

- A submitted manuscript is the version of the article upon submission and before peer-review. There can be important differences between the submitted version and the official published version of record. People interested in the research are advised to contact the author for the final version of the publication, or visit the DOI to the publisher's website.

- The final author version and the galley proof are versions of the publication after peer review.

- The final published version features the final layout of the paper including the volume, issue and page numbers.

Link to publication

\footnotetext{
General rights rights.

- You may freely distribute the URL identifying the publication in the public portal. please follow below link for the End User Agreement:

www.umlib.nl/taverne-license

Take down policy

If you believe that this document breaches copyright please contact us at:

repository@maastrichtuniversity.nl

providing details and we will investigate your claim.
}

Copyright and moral rights for the publications made accessible in the public portal are retained by the authors and/or other copyright owners and it is a condition of accessing publications that users recognise and abide by the legal requirements associated with these

- Users may download and print one copy of any publication from the public portal for the purpose of private study or research.

- You may not further distribute the material or use it for any profit-making activity or commercial gain

If the publication is distributed under the terms of Article $25 \mathrm{fa}$ of the Dutch Copyright Act, indicated by the "Taverne" license above, 


\title{
Effects of technological distance on innovation performance under heterogeneous technological orientations
}

\author{
Shanshan Zhu ${ }^{\text {a }}$, John Hagedoorn ${ }^{\text {b,c }}$, Shuhui Zhang ${ }^{\text {a, Fengchao Liu }}{ }^{\text {a, }}$ \\ ${ }^{a}$ School of Economics and Management, Dalian University of Technology, Linggong Road 2, Ganjingzi District, Dalian, 116024, China \\ ${ }^{\mathrm{b}}$ School of Business and Management, Royal Holloway University of London, TW20 OEX, Egham, Surrey, United Kingdom \\ ${ }^{\text {c } U N U-M E R I T, ~} 6211$ AX, Maastricht, the Netherlands
}

\section{A R T I C L E I N F O}

\section{Keywords:}

Technologically short-distance collaboration

Technologically long-distance collaboration

Technological breadth

Technological depth

Knowledge-based view

Behavioural theory

\begin{abstract}
A B S T R A C T
Research and development (R\&D) collaborations are assumed to be important means by which firms facilitate innovation performance; however, collaborations with different kinds of partners may yield different innovation outputs. Building on the knowledge-based view (KBV) and the behavioural theory of the firm, this paper investigates the effects of technologically short-distance $R \& D$ collaborations and technologically long-distance R\&D collaborations on focal firms' innovation performance. The relative magnitudes of these effects shift once the internal technological orientations (i.e., technological breadth and depth) of focal firms are taken into account. The results from a quantitative data set of 203 international new-energy automotive public enterprises indicate that short-distance R\&D collaborations are better for the innovation performance of high-breadth \& high-depth firms and high-breadth \& low-depth firms. However, collaborating with long-distance partners is better for the innovation performance of low-breadth \& high-depth firms. No significant difference was found between the two kinds of collaborations for low-breadth \& low-depth firms. The findings have managerial implications for how firms can effectively select partners to improve their innovation performance.
\end{abstract}

\section{Introduction}

The accumulating innovation literature and reality itself suggest that it is no longer the case that firms conduct all innovative activities behind closed doors. Firms are prone to be devoted to open innovation by crossing organizational boundaries and integrating resources both inside and outside their boundaries (Enkel et al., 2009; Berchicci, 2013). In this way, firms may seize opportunities outside their current business (Vanhaverbeke et al., 2012) and, in combination with external technologies, may unlock their true potential (Chesbrough, 2006; Bogers et al., 2019). As an important approach for inbound open innovation (Lopes and Carvalho, 2018), firms are increasingly adopting collaborations.

Earlier work by Pisano and Teece (1989) elucidated this growth under the lens of transaction cost theory from an economisation perspective. From this perspective, the governance structure of collaborations is understood as an effective mechanism to reduce both production and transaction costs while protecting against opportunism (Gulati and Singh, 1998; Oxley and Sampson, 2004). However, this logic does not capture many of the strategic advantages that collaborations can offer to focal firms. From a value-creating point of view, collaborations provide focal firms with quick access to complementary resources and capabilities by pooling the resources of both parties (Cui and O'Connor, 2012). Thus, collaborations may increase the possibility, quality and efficiency of innovation of focal firms by providing complementary materials (Ahuja, 2000a; Van Beers and Zand, 2014). Moreover, the access to external resources and capabilities provided by collaborations also give rise to opportunities to acquire these resources and capabilities. Focal firms can internalise the know-how and skills underlying their partners' capabilities, which can then be applied in subsequent innovation activities (Giura and Kumar, 2019).

However, not all firms can reap the desired benefits for innovations from collaborations. On the one hand, different partners can provide focal firms with opportunities to access different external resources (Belderbos et al., 2004; Kang and Kang, 2010). On the other hand, heterogeneities of focal firms may lead to different absorptive capacities to recognise, assimilate, and explore even the same external resources (Cohen and Levinthal, 1990; Zobel, 2017; Kratzer et al., 2017; Wang and $\mathrm{Hu}, 2020)$. Thus, it is necessary to simultaneously focus on the external heterogeneities of partners as well as on the internal heterogeneities of

\footnotetext{
* Corresponding author.

E-mail address: liugroup2018@163.com (F. Liu).
} 
focal firms when analysing the association between collaborations and innovation performance. In this study, we focus on research and development (R\&D) collaborations in which knowledge is the most important strategic resource. In doing so, we try to disentangle the differences in the effects of different types of R\&D collaborations (i.e., technologically short-distance collaborations vs technologically long-distance collaborations) on the innovation performance of different technologically oriented focal firms.

To empirically address this question, data on 203 focal firms were used that engaged in R\&D collaborations over a period of 10 years (2005-2014) in the new-energy vehicle industry. R\&D collaborations were divided into technologically short-distance and long-distance collaborations based on the partner technology overlap; this overlap implies whether the partners' knowledge fields are new or familiar to focal firms (Cusumano et al., 2014). The technological orientation of a focal firm was identified by its technology breadth and depth, where breadth reflects the diversity of the firm's knowledge base and depth reflects the firm's reuse of its extant knowledge domains (Katila and Ahuja, 2002; Leiponen and Helfat, 2010; Caner and Tyler, 2015). The obtained results suggest that when a focal firm's technological breadth is low and its technological depth is high, collaborating with partners with long technological distance can benefit the innovation performance of the firm more than collaborating with those with more similar knowledge. However, the innovation performance of a focal firm with high breadth can benefit more when collaborating with technologically short-distance partners. By contrast, the effects of long-distance collaboration and short-distance collaboration on the innovations do not differ for low-breadth and low-depth firms.

Jointly, these findings have important implications for the theoretical understanding of how R\&D collaborations influence the innovation performance of focal firms. Focal firms can be divided into four groups based on their technological orientations (i.e., the combination of technological breadth and technological depth). By combining the knowledge-based view (KBV) with the behavioural theory of the firm, this paper proposes that different types of collaborations present focal firms with opportunities to access different types of external knowledge, while the technological orientations of focal firms influence their proactiveness and capability to integrate the knowledge they access through collaborations with their internal knowledge. Empirically, this paper contributes to collaboration research by applying technology positions to represent technology domains based on the notion of recombinant innovation. Technology positions account for the coupling relationships among technological elements, which permits us to structure precise and fine-grained measures of technological distance, technological breadth and technological depth.

The remainder of this paper is organized as follows. The next section develops the theoretical framework and displays the concepts of technologically short-distance R\&D collaboration and technologically longdistance $R \& D$ collaboration as well as technological orientation. Furthermore, the relationship between R\&D collaboration and innovation performance is explained and testable hypotheses are formulated. The description of the empirical sample and methods is followed by a discussion of the results and relevant conclusions.

\section{Theory background}

\section{1. $R \& D$ collaboration, knowledge access, and innovation performance}

R\&D collaborations are collaborative arrangements between two or more independent organisations that pool their resources to develop new technologies (Hagedoorn, 2002). The KBV proposes that knowledge resources created, stored and utilized by organisations are the most important strategic resources (Grant,1996a, 1996b). For focal firms, R\&D collaborations are an important means of accessing knowledge outside their boundaries (Hagedoorn, 2002; Grant and Baden-Fuller, 2004; Buckley, 2009). After accessing external knowledge from their partners, focal firms can choose to integrate this knowledge with their internal knowledge, thus resulting in recombination innovations (Grant and Baden-Fuller, 2004; Caner and Tyler, 2015; Hagedoorn et al., 2018).

Alliance scholars have assessed which particular characteristics of partners' knowledge pool influence focal firms' utilization of knowledge. The absolute knowledge characteristics of the knowledge bases of partners, such as the diversity of the knowledge pool, were studied first (Sampson, 2007). Considering the redundancy of knowledge, more attention has been focused on the relative knowledge characteristics of partners' knowledge pools, among which technological distance has received the most attention.

Technological distance is the extent to which the technical knowledge domains of partners differ from the domains in which focal firms are active (Kok et al., 2020). Early studies insisted that firms need to possess prior related knowledge to assimilate external knowledge. Increased technological distance between partners will thus lead to decreased relative absorptive capacity, thereby reducing the learning effect from partners (Lane and Lubatkin, 1998). While earlier studies understood technological distance as an obstacle for focal firms in improving innovation outcomes through alliances, later research showed that more distant collaboration efforts increase the opportunities of focal firms to access unfamiliar knowledge domains (Mowery et al., 1996; Schildt et al., 2012; Kavusan et al., 2016). Subsequently, this allows for richer knowledge recombination activities (Rosenkopf and Nerkar, 2001). Recent studies combined both opposing views and tended to assume the existence of an inverted U-shaped relationship between technological distance and the innovation of focal firms (Subramanian et al., 2018; Kok et al., 2020). However, most of these scholars framed technological distance as the difference between two sets of independent knowledge elements, while ignoring potential ties among the elements and neglecting that the distances perceived by a focal firm and its partner may be different.

Knowledge recombination studies emphasized that even if two firms have the same set of knowledge elements, they may focus on different techniques because of differences in the coupling of these elements (Fleming and Sorenson, 2001; Yayavaram and Ahuja, 2008; Yayavaram et al., 2018). The present study used technology positions to represent firms' technological knowledge domains (Aharonson and Schilling, 2016). Expressed as a binary vector, a technology position is a unique combination of all existing knowledge elements (Aharonson and Schilling, 2016). ${ }^{1}$ Thus, new technology positions arise from not only the emergence of new knowledge elements but also from the formation of new ties between the elements.

The technological distance between two firms should not be treated as a symmetric relationship (Cusumano et al., 2014). Therefore, in the present paper, the classification standard of R\&D collaborations is based on partner technological overlap. This overlap is a directional measure that can reflect both the distance and asymmetry in technology knowledge bases between a focal firm and its partner (Cusumano et al., 2014). As shown in Fig. 1, when a partner shares most of its technology positions with the focal firm, the partner technological overlap is high, implying a short technological distance perceived by the focal firm. The

\footnotetext{
${ }^{1}$ Each element can take a value of one (if the element is used by the invention) or zero (if the element is not used by the invention). For example, with 3 knowledge elements, we can consider $2^{3}-1(=7)$ unique combinations as follows: 111, 110, 101, 100, 011, 010, and 001.
} 


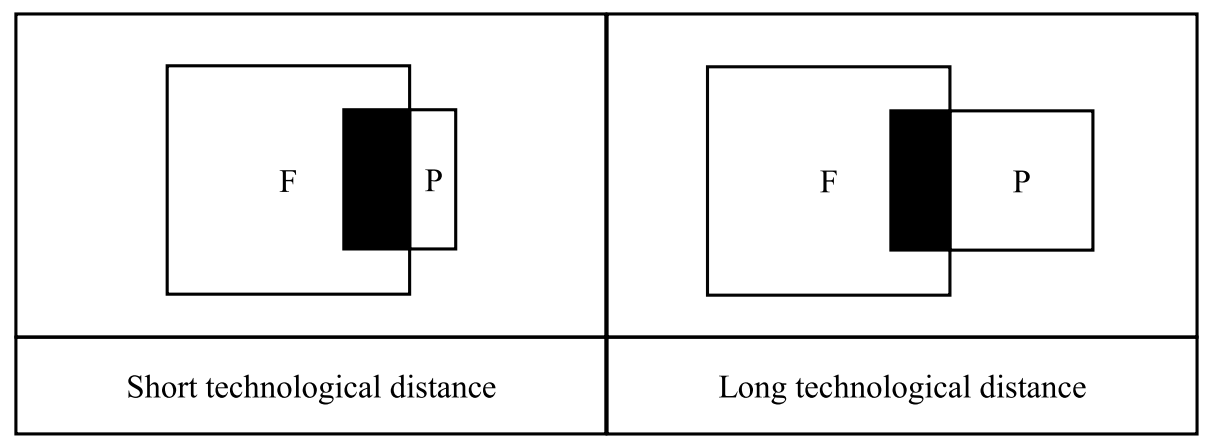

\section{$\mathrm{F}=$ Focal firm's technological knowledge base; $\mathrm{P}=$ Partner's technological knowledge base.}

Fig. 1. Technological distance between focal firms and partners.

R\&D collaboration between these two firms is thus a technologically short-distance collaboration for the focal firm. ${ }^{2}$ Analogously, when a focal firm collaborates with a partner that shares few of its technology positions with the focal firm, the partner technological overlap is low. Such a collaboration is regarded as a technologically long-distance collaboration for the focal firm.

In this case, short-distance partners provide focal firms with more opportunities to access new technological knowledge in familiar domains while long-distance partners provide more opportunities to access new technological knowledge in unfamiliar domains. This distinct difference in external knowledge categories not only enriches the knowledge pool of focal firms to varying degrees, resulting in different integration spaces, but may also require focal firms to mobilize different rules and routines to integrate new knowledge, thus causing differences in cost and efficiency. Thus, short-distance collaborations and longdistance collaborations exert different effects on the innovation performance of focal firms.

\subsection{Technological orientation and knowledge integration}

Although focal firms enter a new collaboration in anticipation of new integration opportunities by accessing external knowledge, whether these integration opportunities can be translated into innovations is contingent on various factors. Cohen and Levinthal (1990) pointed out that the capacity of a firm to absorb external knowledge resources is largely a function of the firm's level of prior related knowledge. Focal firms' internal knowledge structures, such as technology scope or technology depth, have been confirmed to influence the relationship between R\&D collaborations and innovation performance (Lin and Wu, 2010; Caner and Tyler, 2015). Following this stream, the current study constructed a comprehensive factor-the internal technological orientation of the focal firm-as a boundary condition which influences the effectiveness of technological distance by influencing the integration process of the accessed knowledge.

Technological orientation covers both the technological breadth and depth of a focal firm. A firm's technological breadth refers to the number of technology positions in which the firm is active and thus reflects the

\footnotetext{
${ }^{2}$ If the distance between this focal firm and this partner was calculated by symmetric measures (e.g., the Euclidean distance and the cosine-measure (Vom Stein et al., 2015)), this distance would be much higher as the focal firm possesses many technology positions that are not possessed by the partner. In fact, such technology positions would not be counted in the distance perceived by the focal firm. Thus, partner technological overlap could be a more suitable measure to calculate the technological distance perceived by the focal firm, as it omits exclusive technology positions of the focal firm and focuses on the exclusive technology positions of the partner.
}

diversity of the firm's technological knowledge. A firm's technological depth refers to the number of patents included in its technology positions and thus represents the degree to which existing knowledge is reused or exploited by the firm (Katila and Ahuja, 2002; Boh et al., 2014; Caner and Tyler, 2015). Firms may use some pre-existing technological knowledge elements and configurations repeatedly, while others may be used only once. Therefore, technology breadth and depth are two distinct dimensions of a firm's knowledge base that together reflect both the structure and content of the firm's knowledge (Farazi et al., 2019).

Following Farazi et al. (2019), Fig. 2 divides focal firms into four types based on their knowledge orientations: (1) The first type, the so-called ' $\mathrm{H}-\mathrm{H}$ ' firms, are both broad and deep in their technological knowledge base. According to the recombination view, these firms have an abundance of opportunities to recombine their knowledge elements within the firms (Carnabuci and Operti, 2013); moreover, they possess competitive core technology domains (Kim et al., 2016). (2) 'H-L' firms have developed their technological resources over a broad range of technology positions but are not deeply specialised in any of them. Similar to the first type of firms, these firms do not lack opportunities to recombine their knowledge elements; however, they may not know their advantageous technical fields. (3) 'L-H' firms possess knowledge bases that are deep but not broad. In contrast to 'H-L' firms, 'L-H' firms can easily identify their core technology domains but lack opportunities for recombination innovation. (4) Finally, 'L-L' firms are firms whose knowledge bases are neither deep nor broad. This means that these firms lack both recombination opportunities and core technology competitiveness within their boundaries.

A focal firm's internal technological orientation affects its proactiveness towards integrating external knowledge accessed in R\&D collaborations. Here, proactiveness reflects the extent of efforts to identify potentially valuable integration opportunities of both internal and external knowledge and to initiate actions in response to the identified opportunities (Prashantham et al., 2020). A high level of proactiveness

\begin{tabular}{|c|c|c|}
\hline & Low breadth & High breadth \\
\hline $\begin{array}{c}\text { High } \\
\text { depth }\end{array}$ & L-H firms & H-H firms \\
\hline $\begin{array}{c}\text { Low } \\
\text { depth }\end{array}$ & L-L firms & H-L firms \\
\hline
\end{tabular}

Fig. 2. Technological orientation of focal firms. 
indicates that the focal firm is willing to invest its limited resources (e.g., money, human resources, and time) into integration, which further contributes to the success of turning potential integration opportunities into innovations. As stated by behavioural theory, the behaviour of firms is problem-driven (Greve, 2003). Applying this logic, focal firms would be more proactive when integrating new knowledge that is needed and valuable for solving their technological problems. Furthermore, Greve (2003) and Eggers et al. $(2018,2019)$ pointed out that firms have higher risk tolerance for actions that can solve their problems. Technological problems are identified based on the existing knowledge structure and content of focal firms, which can be reflected through their technological orientations.

The technological orientations of firms also affect their capabilities to integrate knowledge accessed from their partners. Strong capabilities imply that every piece of effort contributes more to integrations related to accessed knowledge. According to KBV, focal firms usually use four mechanisms to integrate new knowledge that has been accessed by collaborations: rules and directives, sequencing, routines, and group problem solving (Grant, 1996a, 1996b). The operation of these knowledge-integration mechanisms within firms depends upon common knowledge that has been built up through the accumulation of knowledge (Grant, 1996b). On the one hand, the wider the technological breadth, the more knowledge elements can be recombined (Yayavaram and Ahuja, 2008; Leiponen and Helfat, 2010; Kim et al., 2016), and the more rules and directives, sequencing, routines, and problem-solving processes for integrating these elements may have been developed by the focal firm (Grant, 1996a, 1996b). On the other hand, the repeated use of specific technology positions helps firms gain experience with the same set of domains and develop a significantly deeper understanding of these positions (Katila and Ahuja, 2002; Caner and Tyler, 2015). Moreover, by repeatedly integrating the same knowledge, firms can develop higher-level and more sophisticated common knowledge to refine directions, sequencing, and routines within these positions. Therefore, technological breadth and depth co-affect integrating mechanisms; and more competent integration mechanisms imply stronger integration capabilities.

In summary, the above arguments suggest that the internal technological orientation of a focal firm influences its proactiveness and capability to integrate specific types of external knowledge. Furthermore, sufficient proactiveness and capability are necessary for firms to integrate accessed knowledge; either low proactiveness or weak capability would hinder firms from successfully translating integration opportunities into innovations.

\section{Hypotheses}

\subsection{Collaborations and innovation performance of $\mathrm{H}-\mathrm{H}$ firms}

First, an $\mathrm{H}-\mathrm{H}$ focal firm is less proactive in integrating knowledge in new fields accessed from technologically long-distance partners compared with knowledge in familiar fields accessed from shortdistance partners. $\mathrm{H}-\mathrm{H}$ firms are typically not eager to expand their technology pool through long-distance collaborations. By mastering many knowledge elements and coupling relationships that enhance their recombination opportunities (Fleming and Sorenson, 2001; Wiklund and Shepherd, 2003), these firms are more likely to assume that their existing routines and knowledge are sufficient. $\mathrm{H}-\mathrm{H}$ firms also have established competitive core technologies by repeatedly using specific internal knowledge domains, and they would face relatively high risks if they were to change their existing technology landscape by exploring completely unfamiliar knowledge (Fleming, 2001). According to behavioural theory, such firms focus on the loss of these advantages and are less willing to take risks (Tversky and Kahneman, 1979; Denrell and March 2001; Eggers and Kaul, 2018). Consequently, they are unlikely to spend much resources integrating unfamiliar knowledge from long-distance partners.
Second, integrating knowledge that has been accessed from shortdistance partners may be more efficient than integrating knowledge from long-distance partners because of economies of scale (Grant and Baden-Fuller, 2004; Caner and Tyler, 2015). H-H firms mainly access knowledge in familiar technology positions when they are embedded in technologically short-distance collaborations. These firms can use existing directions, sequencing, and routines to integrate new external knowledge in familiar domains because of the similarity of the internal and the external knowledge (Caner et al., 2017). Additionally, the established sophisticated common knowledge of such firms can eliminate barriers to communication and knowledge transfer between employees in familiar domains, thus increasing the efficiency of integration. By contrast, when integrating external new knowledge in new domains accessed from long-distance partners, formalised integration mechanisms cannot be used directly, and common knowledge is insufficient to support the construction of new mechanisms. Developing more new communication channels and new integrating routines will cost focal firms more resources and time (Zahra and George, 2002), which reduces the efficiency of integration.

Given the relatively low proactiveness of $\mathrm{H}-\mathrm{H}$ focal firms to learn new knowledge in unfamiliar domains and the economic efficiency of scale for integrating knowledge in familiar domains, this paper proposes the following hypothesis:

Hypothesis 1. For H-H firms, technologically short-distance collaborations are more conducive to the improvement of their innovation performance than technologically long-distance collaborations.

\subsection{Collaborations and innovation performance of $H-L$ firms}

First, similar to $\mathrm{H}-\mathrm{H}$ firms, H-L focal firms are more proactive in integrating knowledge in familiar fields accessed from short-distance partners than knowledge in unfamiliar fields accessed from longdistance partners. On the one hand, as explained above, the firm's high technological breadth reduces the demands for new knowledge in new domains because this high breadth leads to abundant opportunities for knowledge integration (Fleming and Sorenson, 2001; Wiklund and Shepherd, 2003; Caner et al., 2017). On the other hand, despite this high technological breadth, such a firm may not concentrate on any of its knowledge positions (Miller et al., 2007). Therefore, the firm has no obvious and competitive core technologies. Driven by this limitation (Dothan and Lavie, 2016; Eggers and Kaul, 2018), the firm is attracted to acquiring and integrating new knowledge in familiar domains via short-distance collaboration to help the firm pick up and enhance its core technologies (Caner et al., 2017). Thus, the focal firm prefers to exert efforts to integrate knowledge accessed by short-distance collaborations.

Second, based on the existing knowledge base, H-L firms are better at integrating external knowledge in familiar domains. On the one hand, as presented above, knowledge is subject to economies of scale (Grant and Baden-Fuller, 2004). Integrating new knowledge in familiar domains by using established integration rules and routines, albeit not refined, costs less than integrating knowledge in unfamiliar domains by creating new integration mechanisms and communication channels (Grant, 1996b; Grant and Baden-Fuller, 2004). On the other hand, integrating new knowledge from short-distance partners prompts focal firms to focus on specific domains; the approximate recombination in these domains will refine their established integrating routines and problem-solving processes and increase common knowledge among employees (Argyres et al., 2020). These mechanisms and common knowledge can then be applied to subsequent knowledge integration, thus improving the efficiency of innovation (Grant, 1996b). By contrast, when integrating knowledge from long-distance partners, an H-L focal firm tries to add new knowledge domains to its technology landscape; consequently, the firm will further dilute its limited attention and resources in order to establish new integration mechanisms and communication channels. In 
this case, a number of knowledge domains may suffer from underinvestment; additionally, the integration mechanisms may be more complex and weaker and the bandwidth of communication channels may narrow, which will increase uncertainty and the possibility of error transmission (Ghosh et al., 2014; Caner et al., 2017; Argyres et al., 2020) when integrating knowledge. As a result, firms will face more integration failures related to innovations.

Thus, this paper proposes that H-L focal firms prefer to invest in short-distance collaborations to form core technology competence; moreover, the focused attention and the reuse and refinement of certain mechanisms make it more efficient to integrate knowledge in familiar domains. Therefore, the following is hypothesised:

Hypothesis 2. For H-L firms, technologically short-distance collaborations are more conducive to the improvement of their innovation performance than technologically long-distance collaborations.

\subsection{Collaborations and innovation performance of $L-H$ firms}

First, in contrast to firms with high breadth, an L-H firm is more proactive in integrating knowledge in new fields by collaborating with long-distance partners. As suggested by previous work, an invention can be defined as either a new combination of knowledge elements or as a new relationship between previously combined knowledge elements (Aharonson and Schilling, 2016; Fleming and Sorenson, 2001). For L-H firms, low technological breadth and high technological depth limit their attention to few technology domains, which leads to a shortage of integrating materials for recombination. Under this circumstance, firms may realise that their existing knowledge elements and routines are no longer sufficient to achieve the desired innovation performance. Focusing on the prospect of gain, such firms will be stimulated to invest more in integrating unfamiliar knowledge (Karbowski and Prokop, 2020) and tolerate relatively high risks (Eggers and Kaul, 2018; Eggers and Suh, 2019); therefore, firms prefer to exert more efforts to acquire knowledge from long-distance partners to expand their knowledge pool and recombination space.

Second, because of path-dependence, new knowledge accessed by short-distance collaborations may constrain the capability of L-H firms to integrate external knowledge with internal knowledge, while new knowledge accessed by long-distance collaborations may not. The skills of L-H focal firms in reconfiguring limited familiar knowledge elements provides mature rules and routines for integrating knowledge in familiar domains (Caner and Tyler, 2015). These rules and routines will be further applied when integrating knowledge accessed by short-distance collaborations. However, given their limited number and complexity, these rules and routines are more likely to be solidified, thus causing path-overdependence in knowledge integration and ultimately leading to a decline in the marginal utility of R\&D efforts in innovation (Helfat, 1994). By contrast, integrating external knowledge in unfamiliar domains with internal knowledge is a more complex task (Caner and Tyler, 2015; Caner et al., 2017), which prompts L-H focal firms to activate group problem-solving functions and establish new integrating rules and routines (Grant, 1996a, 1996b). The integrating mechanisms therefore become more diverse and flexible, which will contribute to the vitality of the firms' integration capability as well as the sustainability of the firms' innovation outputs.

Accordingly, this paper proposes that compared with short-distance collaborations, long-distance collaborations provide $\mathrm{L}-\mathrm{H}$ focal firms with more integrating opportunities and help avoid the lock-in of integrating mechanisms. This leads to the following hypothesis:

Hypothesis 3. For L-H firms, technologically long-distance collaborations are more conducive to the improvement of their innovation performance than technologically short-distance collaborations.

\subsection{Collaborations and innovation performance of $L-L$ firms}

First, an L-L firm may be proactive in integrating knowledge both in new fields via collaborations with long-distance partners and in familiar fields via collaborations with short-distance partners. When a focal firm's technological breadth and depth are both low, the firm's narrow knowledge scope limits the diversity of its knowledge domains and further narrows recombination opportunities. Moreover, the firm does not have competitive core technologies as it does not hold an advantage in these limited technology positions. Thus, following the problemdriven principle (Coccia, 2017; Eggers and Kaul, 2018), such L-L firms not only desire to expand their integrating space by acquiring knowledge from long-distance partners, but also want to consolidate their core technologies by integrating knowledge from short-distance partners. No generally accepted theory has identified which kind of proactiveness is higher.

Second, although L-L firms have the desire to integrate knowledge accessed via collaborations, proactiveness to integrate knowledge is a necessary but not sufficient condition for innovation. Firms must also possess the capabilities to integrate such knowledge. As shown by the knowledge base, the innovation experience of an L-L firm is weak and often lacks continuity in time. In other words, the innovation activities of such firms are high in uncertainty and contingency (Caner et al., 2017), which suggests that such firms may not have adequate resources and orderly integration mechanisms even in their already existing domains. Under this circumstance, the attempt of an L-L firm to integrate external new knowledge accessed from partners (independent of the type of partners), often requires the exploration of new rules, sequencing, routines and group problem solving (Grant, 1996b). All of these efforts require time, money, and human resources, which imposes a huge burden on L-L firms with poor R\&D resources and even jeopardises their unstable technical foundations by draining their limited resources. Thus, it can be difficult for L-L firms to effectively create innovations by integrating external knowledge from collaboration partners.

In summary, L-L focal firms are willing to improve their innovation performance by integrating external knowledge with internal knowledge; however, both high uncertainty and high cost impede the realization of innovation in the short term. Therefore, the following is hypothesised:

Hypothesis 4. For L-L firms, the effects of technologically shortdistance collaborations and those of technologically long-distance collaborations on their innovation performance are not different.

\section{Empirical analysis}

\subsection{Sample}

This paper tests the proposed hypotheses by using a sample of firms from the new-energy vehicle industry, which is a particularly suitable context to study R\&D collaborations. First, firms in this industry have high tendencies to participate in collaborations (Kok et al., 2020). This is because the development of new-energy vehicles is a complicated and systematic process that requires the combination of knowledge from different fields such as physics, electrochemistry, thermofluids and materials sciences. Taking fuel-cell vehicles as an example, many automotive firms in this field initially did not have sufficient knowledge of electrochemistry. By engaging in collaborations with dedicated fuel cell firms, those automotive firms absorbed relevant knowledge of electrochemistry from their partners and then integrated it with their automobile power systems to improve their fuel cell powered vehicles. Ford, for instance, formed an alliance with Ballard Power Systems Inc. to develop hydrogen energy vehicles. Collaborations between competitive firms are also frequent in this industry. A prominent example is the Global Hybrid Cooperation among GM, Daimler, Chrysler, and BMW for 
the development of hybrid cars (Dawid and Hellmann, 2020). Moreover, in the new-energy vehicle field, automakers have a high patenting tendency, which makes their inventive activities more visible.

To construct the sample, we first downloaded all patents concerning new-energy vehicles from the Derwent Innovations Index database using the search phrases 'TS = (electric SAME vehicle or hybrid SAME vehicle or fuel cell SAME vehicle) and DC $=(\mathrm{X} 21)^{\prime}$. These phrases cover hybrid vehicles, electric vehicles, and fuel-cell vehicles. Next, we selected joint patents (via patent applications) that were co-assigned to two or more organisations to identify the R\&D collaborations in the years when these patents were applied for (Capaldo and Messeni, 2015; Fritsch et al., 2020). Based on these partnerships, we finally selected 203 new-energy vehicle manufacturing public firms worldwide as focal firms and constructed an estimation sample with 636 firm-year observations. The focal firms cover all public firms participating in R\&D collaborations at least once during the 2005-2014 period. One firm-year observation covers data of a specific focal firm in a specific year, among which the data about collaborations are based on all bilateral partnerships of that firm in that year. Additionally, we obtained firm-level data from the Compustat database.

\subsection{Measures}

Instrumental variables. A firm's technological breadth and depth are calculated based on the patents the firm applied for within the five years prior to the establishment of the collaboration with its partner. Every patent is assigned to one or more classes according to the International Patent Classification. In this paper, subclasses represent knowledge elements, and a unique combination of these subclasses represents a technology position. The number of technology positions possessed by a focal firm is assumed to be the breadth of the firm's technology; additionally, the number of patent applications in a technology position is assumed to present the depth of the technology position. The average depth of a focal firm's five deepest technology positions is assumed to represent the firm's technological depth (if a firm has fewer than five technology positions, the depth is the average number of patent applications of all of its positions) (see Formula (1)).

depth $=\frac{\sum_{i=1}^{5} n_{i}}{5}$

In Formula (1), $n_{i}$ represents the number of patent applications that belong to technology position $i$. The use of the average depth of the five deepest technology positions instead of all positions can prevent deviation for firms whose depth is only high in some of their technology positions; otherwise, their ability in these positions would be masked.

Dependent variable. The dependent variable is innovation performance (Innovation). In this paper, innovation performance refers to the achievements, especially with regard to the technical aspects, of a firm's R\&D efforts. Following the extensive literature on this topic (Bresman et al., 1999; Zhang et al., 2020), the count of each focal firm's patent applications with regard to new-energy vehicles is used to measure innovation performance. Given that the impact of R\&D collaborations on innovation performance may persist for an extended period of time, innovation performance is measured by the sum of the weighted counts of the patent applications in the three years after the collaboration year (see Formula (2)):

Innovation $_{i t}=0.5 \times a p p_{i t+1}+0.3 \times a p p_{i t+2}+0.2 \times a p p_{i t+3}$

where $t$ represents the year when firm $i$ engaged in collaborations, and $a p p_{i t+1}$ represents the count of firm i's patent applications in year $t+1$.

Independent variable. The independent variable is the ratio of the count of short-distance collaborations to the count of long-distance collaborations (CCratio), which is calculated according to Formula (3):

CCratio $_{i t}=\left(C_{s}+1\right) /\left(C_{l}+1\right)$ where $C_{s}$ represents the number of short-distance partners of firm $i$ in year $t$, and $C_{l}$ represents the number of long-distance partners of firm $i$ in year $t$. An increased number of short-distance partners increases this ratio, while an increase in the number of long-distance partners decreases the ratio.

To specify both technological short-distance collaborations and longdistance collaborations, the technological overlap between focal firms and their partners must first be determined. The partner technological overlap of a focal firm, which ranges from 0 to 1 , is calculated according to Formula (4):

technology overlap $=R / K_{p} \times 100 \%$

where $R$ represents the number of technology positions at the knowledge set intersection between the focal firm and its partner. The knowledge set of the focal firm consists of the technology positions the firm occupied within the five years prior to the year of the collaboration, identified through patent applications. The same applies to the knowledge set of the partner. $K p$ represents the number of technology positions in the partner's knowledge set.

If a partner technological overlap of a focal firm is equal to or greater than $50 \%$, the collaboration between the focal firm and this partner is defined as a short-distance collaboration; however, if the overlap is less than $50 \%$, the collaboration is defined as a long-distance collaboration. For example, focal firm $\mathrm{F}$ occupied 10 technology positions within the past five years while its partner P occupied eight technology positions. Among these positions, $\mathrm{F}$ and $\mathrm{P}$ jointly occupied five positions. In this case, the partner technological overlap of $\mathrm{F}$ equals $67.5 \%$ (5/8), thus, $\mathrm{P}$ is a short-distance partner of $\mathrm{F}$.

Control variables. A number of control variables are constructed to represent both the internal and external characteristics of firms that may influence innovation performance. All control variables are lagged by one year with respect to the dependent variable. First, three control variables for the characteristics of focal firms are included. According to prior research (Rothaermel and Hess, 2007; Berchicci, 2013), human resources and capital resources will certainly have an impact on innovation outputs; thus, (1) a focal firm's size (fsize), measured by the number of employees (in thousands), and (2) R\&D investment ( $f r d$ ) are included. (3) A focal firm's innovation experience (experience), measured by the difference between the year when the firm first applied for a patent and the year when the firm collaborated with its partner, is also used.

Second, three variables are included that control focal firms' external collaboration features. This study controls for the (4) mean patent stock of partners (psize) within the five years before the collaboration-year and the (5) mean frequency of collaborations between a focal firm and its partners (cointense). The former determines the size of the external knowledge pool (Subramanian et al., 2018), and the latter influences the transmission efficiency of knowledge (Ahuja et al., 2012; Wang, 2016). Additionally, the knowledge transfer between universities and firms has been shown to differ from that between firms (Maietta, 2015); thus, a dummy variable is used to show (6) whether the partners of a focal firm include any university (ifuni).

\subsection{Data analysis procedure}

According to focal firms' internal technological orientations technological breadth and technological depth, the total sample of 636 data points was divided into four subsamples (subsample 1: $\mathrm{H}-\mathrm{H}$ firms; subsample 2: H-L firms; subsample 3: L-H firms; subsample 4: L-L firms). The subsample partitioning criteria are shown in Table 1 .

Robust ordinary least squares regressions were used to analyse the total sample including the dummy variables for the four kinds of technological orientations. This was done to illustrate the relatively different roles of technological distance in different focal firms. Furthermore, robust ordinary least squares regressions were used to analyse the four 
Table 1

Subsample partitioning criteria.

\begin{tabular}{|c|c|}
\hline subsamples & partition criteria \\
\hline $\begin{array}{l}\text { Subsample } 1 \\
\mathrm{H}-\mathrm{H}\end{array}$ & $\begin{array}{l}\text { technological breadth } \geq \text { the median of technological breadth of } \\
\text { all samples and technological depth } \geq \text { the median of } \\
\text { technological breadth of all samples }\end{array}$ \\
\hline $\begin{array}{l}\text { Subsample } 2 \mathrm{H}- \\
\quad \text { L }\end{array}$ & $\begin{array}{l}\text { technological breadth } \geq \text { the median of technological breadth of } \\
\text { all samples and technological depth }<\text { the median of } \\
\text { technological breadth of all samples }\end{array}$ \\
\hline $\begin{array}{l}\text { Subsample } 3 \mathrm{~L}- \\
\quad \mathrm{H}\end{array}$ & $\begin{array}{l}\text { technological breadth }<\text { the median of technological breadth of } \\
\text { all samples and technological depth } \geq \text { the median of } \\
\text { technological breadth of all samples }\end{array}$ \\
\hline Subsample 4 L-L & $\begin{array}{l}\text { technological breadth }<\text { the median of technological breadth of } \\
\text { all samples and technological depth }<\text { the median of } \\
\text { technological breadth of all samples }\end{array}$ \\
\hline
\end{tabular}

H-H=High-High, H-L=High-Low, L-H = Low-High, L-L = Low-Low.

subsamples to discern the differences between the effects of shortdistance collaborations and those of long-distance collaborations for a certain kind of focal firm.

\section{Results}

Tables 2-6 present the descriptive statistics and correlations for both the independent and control variables of the total samples and the four subsamples. To overcome the problem of high variance, the dependent variable (innovation) and several control variables ( $f$ size, frd, psize) were $\log$ transformed. No high correlation coefficients were found among the control variables and independent variables. The results of the variance inflation factor test $(1.43,1.36,1.64,1.43$, and 1.21) suggested that multicollinearity is not a concern in these samples.

Table 7 presents the regression results of the entire sample using the interaction terms between the independent variable and the dummy variables for the four types of technological orientations. Models 1 and 2 are the baseline models. The results of model 3 largely support that the effects of technologically short-distance collaborations and longdistance collaborations on the innovation performance of focal firms are discrepant; moreover, the discrepancy varies with the internal knowledge base of focal firms. Model 3 in Table 7 indicates that both the interaction term between the CCratio and the dummy for $\mathrm{H}-\mathrm{H}$ firms and the interaction term between the CCratio and the dummy for H-L firms have positive coefficients; however, the interaction term between the CCratio and the dummy for L-H firms has a significantly negative coefficient. This implies that the relative merits of the two kinds of collaborations differ for $\mathrm{H}-\mathrm{H}, \mathrm{H}-\mathrm{L}$ and L-H firms compared with L-L firms.

Table 8 presents the results of the regression for the four subsamples, divided by technological breadth and depth. Models 1, 3, 5, and 7, which include all control variables, are the baseline models for subsamples 1, 2, 3, and 4, respectively. Models 2, 4, 6, and 8 include the dependent variables. All proposed hypotheses are supported by the obtained results. The key findings are summarized in the following:

First, model 2 shows that the coefficient of CCratio ( $\beta=0.21, p<$ 0.1 ) is positive and statistically significant, implying that collaborating with short-distance partners instead of long-distance partners increases innovation performance more for $\mathrm{H}-\mathrm{H}$ firms. Hence, this finding supports Hypothesis 1 . Second, regarding Hypothesis 2 , CCratio $(\beta=0.37$, $p<0.05$ ) for $\mathrm{H}-\mathrm{L}$ firms in model 4 is positive and statistically significant, thus supporting Hypothesis 2. Third, as shown in model 6, for L-H focal firms, CCratio has a negative and statistically significant coefficient ( $\beta=$ - 0.86, $p<0.05$ ), implying that collaborating with long-distance partners increases innovation performance more. This result supports Hypothesis 3. Fourth, the coefficient of CCratio is not significant for L-L firms, which is consistent with Hypothesis 4.

To test the robustness of the empirical results reported in Table 8, additional analyses were conducted. The average number of patent applications of the 10 deepest technology positions (instead of the five deepest positions) of a focal firm was used to measure the technological depth. This change led to four different subsamples, although the same subsample partitioning criteria were applied. The regression results are shown in Table 9. The results of the robustness tests follow the same trend as the above results.

\section{Discussion and conclusion}

The core proposition of this study is that technologically shortdistance collaborations and long-distance collaborations play different roles in improving the innovation performance of focal firms under different specific levels of internal technological breadth and depth. The results further demonstrate these differences: short-distance collaborations are better for improving innovation performance for $\mathrm{H}-\mathrm{H}$ and $\mathrm{H}-\mathrm{L}$ firms, while long-distance collaborations are better for L-H firms. For L-L firms, neither short-distance collaborations nor long-distance collaborations achieve significant advantages. These findings have implications for research on $\mathrm{R} \& \mathrm{D}$ collaborations as well as for practice and public policy.

\subsection{Implications for theory and research}

First, this study provides an additional empirical validation of the existing assumptions that short-distance collaborations and longdistance collaborations have different effects on the innovation performance of focal firms. By inheriting and improving the view of Grant et al. (2004) and Hagedoorn et al. (2018), this paper suggests that the process of generating innovations using external knowledge from R\&D partners can be divided into two successive processes: knowledge access and knowledge integration. The effects of these two kinds of collaborations differ because they provide focal firms with opportunities to access new knowledge in different technological domains. Furthermore, this paper also demonstrates that the relative magnitudes of the effects of technologically short-distance collaborations and long-distance collaborations on focal firms' innovation performance are not fixed. The relative magnitude varies with changes in focal firms' internal technological orientations, which influence the integration process of the accessed knowledge. This provides a new explanation beyond the inverted-U relationship (Subramanian et al., 2018; Kok et al., 2020) for opposing views (Mowery et al., 1996; Lane and Lubatkin, 1998; Schildt et al., 2012) on the effects of technological distance.

Table 2

Summary statistics and correlation coefficients for key variables in total sample.

\begin{tabular}{|c|c|c|c|c|c|c|c|c|c|c|c|}
\hline \multirow[t]{2}{*}{ Variables } & \multirow[t]{2}{*}{ Obs } & \multirow[t]{2}{*}{ Mean } & \multirow[t]{2}{*}{ SD } & \multicolumn{8}{|c|}{ Correlation coefficient } \\
\hline & & & & 1 & 2 & 3 & 4 & 5 & 6 & 7 & 8 \\
\hline 1. lnInnov & 636 & 2.57 & 1.80 & 1.00 & & & & & & & \\
\hline 2. CCratio & 636 & 0.63 & 0.51 & $0.25^{* * *}$ & 1.00 & & & & & & \\
\hline 3. lnfsize & 636 & 3.24 & 1.47 & $0.63^{* * *}$ & $0.24 * * *$ & 1.00 & & & & & \\
\hline 4. $\operatorname{lnfrd}$ & 636 & 9.56 & 2.11 & $0.58^{* * *}$ & $0.22^{* * *}$ & $0.63^{* * *}$ & 1.00 & & & & \\
\hline 5.experience & 636 & 11.55 & 8.31 & $0.60 * * *$ & $0.18^{* * *}$ & $0.52^{* * *}$ & $0.38^{* * *}$ & 1.00 & & & \\
\hline 6.lnpsize & 636 & 4.66 & 2.51 & 0.01 & $-0.24 * * *$ & 0.02 & 0.01 & -0.01 & 1.00 & & \\
\hline 7.cointense & 636 & 2.54 & 3.61 & $0.33^{* * *}$ & $0.19^{* * *}$ & $0.18^{* * *}$ & $0.22^{* * *}$ & $0.20^{* * *}$ & $0.07 *$ & 1.00 & \\
\hline 8.ifuni & 636 & 0.27 & 0.44 & $0.28 * * *$ & 0.06 & 0.02 & $0.23^{* * *}$ & $0.11^{* * *}$ & $-0.23^{* * *}$ & $0.09^{*}$ & 1.00 \\
\hline
\end{tabular}


Table 3

Summary statistics and correlation coefficients for key variables in subsample 1 .

\begin{tabular}{|c|c|c|c|c|c|c|c|c|c|c|c|}
\hline \multirow[t]{2}{*}{ Variables } & \multirow[t]{2}{*}{ Obs } & \multirow[t]{2}{*}{ Mean } & \multirow[t]{2}{*}{ SD } & \multicolumn{8}{|c|}{ Correlation coefficient } \\
\hline & & & & 1 & 2 & 3 & 4 & 5 & 6 & 7 & 8 \\
\hline 1. lnInnov & 271 & 4.09 & 1.46 & 1.00 & & & & & & & \\
\hline 2. CCratio & 271 & 0.72 & 0.61 & $0.22^{* * *}$ & 1.00 & & & & & & \\
\hline 3.lnfsize & 271 & 4.11 & 1.34 & $0.47^{* * *}$ & $0.20^{* * *}$ & 1.00 & & & & & \\
\hline 4. $\operatorname{lnfrd}$ & 271 & 10.68 & 2.24 & $0.47^{* * *}$ & $0.20^{* * *}$ & $0.57^{* * *}$ & 1.00 & & & & \\
\hline 5.experience & 271 & 17.17 & 6.88 & $0.35^{* * *}$ & $0.18^{* * *}$ & $0.43^{* * *}$ & $0.23^{* * *}$ & 1.00 & & & \\
\hline 6.lnpsize & 271 & 4.76 & 2.17 & -0.03 & $-0.30 * * *$ & -0.05 & -0.04 & -0.07 & 1.00 & & \\
\hline 7.cointense & 271 & 3.55 & 4.96 & $0.24 * * *$ & $0.15^{* * *}$ & 0.05 & $0.12^{*}$ & $0.12^{* *}$ & $0.14^{* *}$ & 1.00 & \\
\hline 8.ifuni & 271 & 0.34 & 0.48 & $0.45^{* * *}$ & 0.06 & 0.04 & $0.31^{* * *}$ & $0.10^{*}$ & -0.09 & $0.11 *$ & 1.00 \\
\hline
\end{tabular}

Table 4

Summary statistics and correlation coefficients for key variables in subsample 2 .

\begin{tabular}{|c|c|c|c|c|c|c|c|c|c|c|c|}
\hline \multirow[t]{2}{*}{ Variables } & \multirow[t]{2}{*}{ Obs } & \multirow[t]{2}{*}{ Mean } & \multirow[t]{2}{*}{ SD } & \multicolumn{8}{|c|}{ Correlation coefficient } \\
\hline & & & & 1 & 2 & 3 & 4 & 5 & 6 & 7 & 8 \\
\hline 1. InInnov & 38 & 2.62 & 1.02 & 1.00 & & & & & & & \\
\hline 2. CCratio & 38 & 0.84 & 0.83 & $0.27 *$ & 1.00 & & & & & & \\
\hline 3.lnfsize & 38 & 3.95 & 1.36 & $0.62^{* * *}$ & 0.13 & 1.00 & & & & & \\
\hline 4. lnfrd & 38 & 9.57 & 1.71 & $-0.31^{*}$ & -0.03 & -0.05 & 1.00 & & & & \\
\hline 5.experience & 38 & 12.38 & 6.20 & 0.11 & -0.16 & 0.02 & $-0.36 * *$ & 1.00 & & & \\
\hline 6.lnpsize & 38 & 4.74 & 2.40 & -0.02 & $-0.41 * * *$ & -0.07 & -0.03 & 0.20 & 1.00 & & \\
\hline 7.cointense & 38 & 2.47 & 2.97 & 0.20 & $0.43^{* *}$ & 0.24 & $0.42^{* * *}$ & $-0.37 * *$ & -0.24 & 1.00 & \\
\hline 8.ifuni & 38 & 0.15 & 0.36 & $-0.42^{* * *}$ & 0.07 & $-0.51 * * *$ & 0.21 & -0.20 & $-0.38 * *$ & -0.04 & 1.00 \\
\hline
\end{tabular}

Table 5

Summary statistics and correlation coefficients for key variables in subsample 3.

\begin{tabular}{|c|c|c|c|c|c|c|c|c|c|c|c|}
\hline \multirow[t]{2}{*}{ Variables } & \multirow[t]{2}{*}{ Obs } & \multirow[t]{2}{*}{ Mean } & \multirow[t]{2}{*}{ SD } & \multicolumn{8}{|c|}{ Correlation coefficient } \\
\hline & & & & 1 & 2 & 3 & 4 & 5 & 6 & 7 & 8 \\
\hline 1. InInnov & 54 & 2.00 & 0.89 & 1.00 & & & & & & & \\
\hline 2. CCratio & 54 & 0.52 & 0.25 & -0.19 & 1.00 & & & & & & \\
\hline 3.lnfsize & 54 & 2.41 & 0.99 & $0.38^{* *}$ & $-0.23^{*}$ & 1.00 & & & & & \\
\hline 4. $\operatorname{lnfrd}$ & 54 & 8.79 & 1.22 & 0.18 & -0.13 & $0.56 * * *$ & 1.00 & & & & \\
\hline 5.experience & 54 & 10.02 & 7.09 & -0.17 & -0.07 & 0.08 & -0.13 & 1.00 & & & \\
\hline 6.lnpsize & 54 & 5.62 & 2.70 & -0.05 & $-0.24^{*}$ & 0.02 & 0.17 & -0.08 & 1.00 & & \\
\hline 7.cointense & 54 & 2.16 & 2.59 & $0.25^{*}$ & 0.04 & 0.02 & 0.01 & -0.11 & -0.07 & 1.00 & \\
\hline 8.ifuni & 54 & 0.31 & 0.47 & 0.04 & $0.29 * *$ & -0.01 & -0.07 & -0.11 & $-0.62 * * *$ & -0.05 & 1.00 \\
\hline
\end{tabular}

Table 6

Summary statistics and correlation coefficients for key variables in subsample 4.

\begin{tabular}{|c|c|c|c|c|c|c|c|c|c|c|c|}
\hline \multirow[t]{2}{*}{ Variables } & \multirow[t]{2}{*}{ Obs } & \multirow[t]{2}{*}{ Mean } & \multirow[t]{2}{*}{ SD } & \multicolumn{8}{|c|}{ Correlation coefficient } \\
\hline & & & & 1 & 2 & 3 & 4 & 5 & 6 & 7 & 8 \\
\hline 1. lnInnov & 273 & 1.18 & 0.92 & 1.00 & & & & & & & \\
\hline 2. CCratio & 273 & 0.54 & 0.32 & $0.11^{*}$ & 1.00 & & & & & & \\
\hline 3.lnfsize & 273 & 2.46 & 1.11 & $0.33^{* * *}$ & 0.10 & 1.00 & & & & & \\
\hline 4. $\operatorname{lnfrd}$ & 273 & 8.60 & 1.56 & $0.36^{* * *}$ & $0.11^{*}$ & $0.55^{* * *}$ & 1.00 & & & & \\
\hline 5.experience & 273 & 6.21 & 6.21 & $0.26^{* * *}$ & 0.03 & $0.19 * * *$ & $0.12^{*}$ & 1.00 & & & \\
\hline 6.lnpsize & 273 & 4.37 & 2.75 & $-0.10^{*}$ & $-0.24^{* * *}$ & -0.05 & 0.00 & -0.09 & 1.00 & & \\
\hline 7.cointense & 273 & 1.64 & 1.30 & $0.24 * * *$ & -0.01 & 0.10 & 0.10 & $0.11^{*}$ & 0.03 & 1.00 & \\
\hline 8.ifuni & 273 & 0.20 & 0.40 & $0.10^{*}$ & -0.01 & $-0.10 *$ & 0.03 & 0.03 & $-0.30^{* * *}$ & -0.02 & 1.00 \\
\hline
\end{tabular}

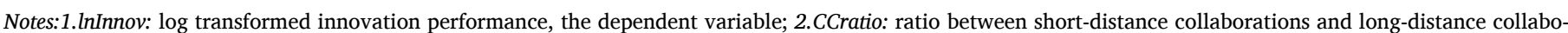

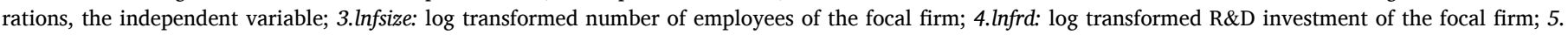

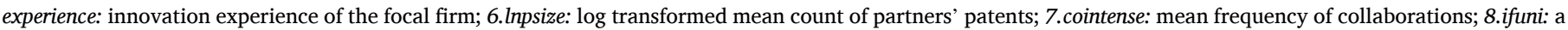
dummy variable that indicates whether the partners include any university.

${ }^{*} \mathrm{p}<0.1 ; *{ }^{*} \mathrm{p}<0.05 ;{ }^{* * * \mathrm{p}}<0.01$ (two-tailed).

Second, the subjective initiative of focal firms is emphasized in the process of technology integration. It is generally assumed that the formation of collaborative relationships is a firm's proactive choice after assessing both gains and risks (Ahuja, 2000b; Oxley and Sampson, 2004; Farazi et al., 2019). However, after the formation of a collaboration, most studies focus on the capabilities of focal firms in the learning and utilizing processes, while ignoring firms' initiative (Sampson, 2007; Van
Beers and Zand, 2014; Zobel, 2017; Wang and Hu, 2020). By combining behavioural theory and KBV, this paper constructs a proactiveness-capability framework. This framework emphasises not only what focal firms can do (i.e., capability) but also what they would like to do (i.e., proactiveness) with the newly accessed knowledge based on their technological orientations. Firms gain the right to access external knowledge from collaborations; however, they can still choose 
Table 7

Regression estimates of innovation performance of focal firms for the total sample.

\begin{tabular}{|c|c|c|c|c|}
\hline & Variables & Model 1 & Model 3 & Model2 \\
\hline \multirow[t]{11}{*}{$\begin{array}{c}\text { Independent } \\
\text { variables }\end{array}$} & \multicolumn{2}{|l|}{ CCratio } & $\begin{array}{l}0.21 * * \\
(0.091)\end{array}$ & $\begin{array}{l}-0.07 \\
(0.183)\end{array}$ \\
\hline & \multirow{2}{*}{\multicolumn{2}{|c|}{$H-H$}} & & $1.68 * * *$ \\
\hline & & & & $(0.180)$ \\
\hline & \multirow{2}{*}{\multicolumn{2}{|c|}{$H-L$}} & & $0.55 * * *$ \\
\hline & & & & $(0.299)$ \\
\hline & \multirow{2}{*}{\multicolumn{2}{|c|}{$L-H$}} & & $1.08 * * *$ \\
\hline & & & & $(0.249)$ \\
\hline & \multicolumn{2}{|l|}{$H-H^{*}$ ratio } & & $0.28(0.216)$ \\
\hline & \multirow{2}{*}{\multicolumn{2}{|c|}{$H-L^{*}$ ratio }} & & $0.47^{* *}$ \\
\hline & & & & $(0.201)$ \\
\hline & \multicolumn{2}{|l|}{$L-H^{*}$ ratio } & & $\begin{array}{l}-0.86^{* *} \\
(0.341)\end{array}$ \\
\hline \multirow[t]{6}{*}{ Internal controls } & \multirow[t]{2}{*}{ Lnfsize } & $0.40 * * *$ & $0.39 * * *$ & $0.27^{* * *}$ \\
\hline & & $(0.049)$ & $(0.050)$ & $(0.039)$ \\
\hline & \multirow[t]{2}{*}{ Lnfrd } & $0.15^{* * *}$ & $0.14 * * *$ & $0.09 * * *$ \\
\hline & & $(0.034)$ & $(0.035)$ & $(0.027)$ \\
\hline & \multirow[t]{2}{*}{ Experience } & $0.07^{* * *}$ & $0.07 * * *$ & $0.03^{* * *}$ \\
\hline & & $(0.009)$ & $(0.009)$ & $(0.006)$ \\
\hline \multirow[t]{12}{*}{ External controls } & \multirow[t]{2}{*}{ lnpsize } & $0.04 * *$ & $0.05^{* * *}$ & $0.03 *(0.014)$ \\
\hline & & $(0.016)$ & $(0.017)$ & \\
\hline & \multirow[t]{2}{*}{ cointense } & $0.08^{* * *}$ & $0.07 * * *$ & $0.05^{* * *}$ \\
\hline & & $(0.012)$ & $(0.011)$ & $(0.010)$ \\
\hline & \multirow[t]{2}{*}{ ifuni } & $0.83^{* * *}$ & $0.84 * * *$ & $0.77 * * *$ \\
\hline & & $(0.114)$ & $(0.114)$ & $(0.096)$ \\
\hline & years & included & included & Included \\
\hline & \multirow[t]{2}{*}{ _cons } & $-1.62^{* * *}$ & $-1.73^{* * *}$ & $-0.84 * * *$ \\
\hline & & $(0.397)$ & $(0.349)$ & $(0.291)$ \\
\hline & $N$ & 636 & 636 & 636 \\
\hline & $F$ & 77.32 & 77.47 & 90.31 \\
\hline & $R^{2}$ & 0.61 & 0.62 & 0.73 \\
\hline
\end{tabular}

Standard errors in parentheses.

$* \mathrm{p}<0.1 ; * * \mathrm{p}<0.05 ; * * * \mathrm{p}<0.01$ (two-tailed).

to invest resources into integrating specific kinds of accessed knowledge.

Third, the concept of technological orientation is developed which emphasises the joint effect of focal firms' internal technological breadth and depth in collaboration research. As influencing factors or moderating factors for innovation performance, firms' internal technological breadth and depth have previously often been treated independently (Katila and Ahuja, 2002; Leiponen and Helfat, 2010; Lin and Wu, 2010; Caner and Tyler, 2015). Farazi et al. (2019) presented one of the few studies that analysed both comprehensively and divided firms into four groups based on breadth and depth. Comparing the results of the four subsamples used in the present study shows that the relative advantages of partners in focal firms' innovation performance change with technological orientation. This means that considering technological breadth or depth alone cannot help focal firms accurately choose better partners for innovation improvement. The proactiveness-capability framework emphasises that the accessed knowledge can only be

Table 9

Regression results for the robustness tests.

\begin{tabular}{|c|c|c|c|c|c|}
\hline & Variable & $\mathrm{H}-\mathrm{H}$ & H-L & L-H & L-L \\
\hline & & $\begin{array}{l}\text { Model } 1 \\
\text { (H1) }\end{array}$ & $\begin{array}{l}\text { Model } 2 \\
(\mathrm{H} 2)\end{array}$ & $\begin{array}{l}\text { Model } 3 \\
\text { (H3) }\end{array}$ & $\begin{array}{l}\text { Model } 4 \\
(\mathrm{H} 4)\end{array}$ \\
\hline $\begin{array}{c}\text { Independent } \\
\text { variables }\end{array}$ & CCratio & $\begin{array}{l}0.20 * \\
(0.119)\end{array}$ & $\begin{array}{l}0.47^{* * *} \\
(0.113)\end{array}$ & $\begin{array}{l}-0.70 * \\
(0.361)\end{array}$ & $\begin{array}{l}-0.11 \\
(0.189)\end{array}$ \\
\hline \multirow[t]{3}{*}{$\begin{array}{l}\text { Internal } \\
\text { controls }\end{array}$} & Lnfsize & $\begin{array}{l}0.29^{* * *} \\
(0.064)\end{array}$ & $\begin{array}{l}0.11 \\
(0.120)\end{array}$ & $\begin{array}{l}0.45^{* *} \\
(0.199)\end{array}$ & $\begin{array}{l}0.14 * * \\
(0.057)\end{array}$ \\
\hline & Lnfrd & $\begin{array}{l}0.06 \\
(0.039)\end{array}$ & $\begin{array}{l}0.02 \\
(0.060)\end{array}$ & $\begin{array}{l}-0.15 \\
(0.208)\end{array}$ & $\begin{array}{l}0.13^{* * *} \\
(0.03)\end{array}$ \\
\hline & experience & $\begin{array}{l}0.04^{* * *} \\
(0.012)\end{array}$ & $\begin{array}{l}0.03^{*} \\
(0.014)\end{array}$ & $\begin{array}{l}-0.01 \\
(0.010)\end{array}$ & $\begin{array}{l}0.03^{* * *} \\
(0.010)\end{array}$ \\
\hline \multirow[t]{8}{*}{$\begin{array}{l}\text { External } \\
\text { controls }\end{array}$} & lnpsize & $\begin{array}{l}0.06^{* *} \\
(0.029)\end{array}$ & $\begin{array}{l}-0.02 \\
(0.049)\end{array}$ & $\begin{array}{l}0.08 \\
(0.072)\end{array}$ & $\begin{array}{l}-0.02 \\
(0.019)\end{array}$ \\
\hline & cointense & $\begin{array}{l}0.03^{* * *} \\
(0.010)\end{array}$ & $\begin{array}{l}0.08^{*} \\
(0.034)\end{array}$ & $\begin{array}{l}0.08^{* *} \\
(0.031)\end{array}$ & $\begin{array}{l}0.17 * * * \\
(0.047)\end{array}$ \\
\hline & Ifuni & $\begin{array}{l}1.19 * * * \\
(0.154)\end{array}$ & $\begin{array}{l}0.01 \\
(0.453)\end{array}$ & $\begin{array}{l}0.56 \\
(0.516)\end{array}$ & $\begin{array}{l}0.27^{* *} \\
(0.123)\end{array}$ \\
\hline & Years & included & included & included & included \\
\hline & _cons & $\begin{array}{l}0.73 \\
(0.539)\end{array}$ & $\begin{array}{l}-0.11 \\
(0.953)\end{array}$ & $\begin{array}{l}1.65 \\
(1.627)\end{array}$ & $\begin{array}{l}-1.01 * * * \\
(0.367)\end{array}$ \\
\hline & $N$ & 269 & 40 & 58 & 269 \\
\hline & $F$ & 17.01 & - & 2.68 & 7.25 \\
\hline & $R^{2}$ & 0.48 & 0.83 & 0.34 & 0.31 \\
\hline
\end{tabular}

H-H=High-High, H-L=High-Low, L-H = Low-High, L-L = Low-Low. Standard errors in parentheses.

*p $<0.1 ; * * \mathrm{p}<0.05 ; * * * \mathrm{p}<0.01$ (two-tailed).

Table 8

Regression estimates of innovation performance of focal firms for the subsamples.

\begin{tabular}{|c|c|c|c|c|c|c|c|c|}
\hline \multirow[t]{2}{*}{ Variable } & \multicolumn{2}{|l|}{$\mathrm{H}-\mathrm{H}$} & \multicolumn{2}{|l|}{$\mathrm{H}-\mathrm{L}$} & \multicolumn{2}{|l|}{ L-H } & \multicolumn{2}{|l|}{ L-L } \\
\hline & Model 1 & Model 2 (H1) & Model 3 & Model 4 (H2) & Model 5 & Model 6 (H3) & Model 7 & Model 8(H4) \\
\hline \multicolumn{9}{|c|}{$\begin{array}{c}\text { Independent } \\
\text { variables }\end{array}$} \\
\hline CCratio & & $0.21 *(0.120)$ & & $\begin{array}{l}0.37 * * \\
(0.148)\end{array}$ & & $\begin{array}{l}-0.86^{* *} \\
(0.385)\end{array}$ & & $-0.11(0.188)$ \\
\hline \multicolumn{9}{|c|}{ Internal controls } \\
\hline Infsize & $\begin{array}{l}0.28 * * * \\
(0.066)\end{array}$ & $\begin{array}{l}0.27 * * * \\
(0.066)\end{array}$ & $\begin{array}{l}0.30 * * \\
(0.122)\end{array}$ & $0.23 *(0.118)$ & $0.41 *(0.196)$ & $0.33 *(0.191)$ & $0.15^{* * *}(0.057)$ & $0.15^{* * *}(0.057)$ \\
\hline $\operatorname{lnfrd}$ & $0.08 * *(0.038)$ & $0.07 *(0.039)$ & $-0.13(0.078)$ & $-0.06(0.076)$ & $-0.05(0.176)$ & $-0.05(0.175)$ & $0.12^{* * *}(0.039)$ & $0.13^{* * *}(0.039)$ \\
\hline experience & $\begin{array}{l}0.04 * * * \\
(0.012)\end{array}$ & $\begin{array}{l}0.04 * * * \\
(0.012)\end{array}$ & $-0.02(0.021)$ & $-0.01(0.016)$ & $\begin{array}{l}-0.03^{* *} \\
(0.013)\end{array}$ & $\begin{array}{l}-0.03^{* *} \\
(0.013)\end{array}$ & $0.02^{* * *}(0.009)$ & $0.02^{* * *}(0.009)$ \\
\hline \multicolumn{9}{|c|}{ External controls } \\
\hline Lnpsize & $0.03(0.027)$ & $0.05 *(0.029)$ & $-0.07(0.052)$ & $-0.04(0.049)$ & $0.01(0.080)$ & $0.00(0.080)$ & $-0.01(0.019)$ & $-0.02(0.020)$ \\
\hline Cointense & $\begin{array}{l}0.04 * * * \\
(0.010)\end{array}$ & $\begin{array}{l}0.03 * * * \\
(0.010)\end{array}$ & $0.03(0.051)$ & $0.02(0.041)$ & $0.08 * * *(0.031)$ & $0.08^{* * *}(0.027)$ & $0.14 * * *(0.051)$ & $0.14^{* * *}(0.051)$ \\
\hline Ifuni & $\begin{array}{l}1.16^{* * *} \\
(0.159)\end{array}$ & $\begin{array}{l}1.17 * * * \\
(0.156)\end{array}$ & $-0.61(0.422)$ & $-0.33(0.395)$ & $0.18(0.499)$ & $0.32(0.532)$ & $0.29 * *(0.124)$ & $0.27 * *(0.124)$ \\
\hline $\begin{array}{l}\text { Years } \\
\text { _cons }\end{array}$ & $\begin{array}{l}\text { included } \\
0.72(0.524)\end{array}$ & $\begin{array}{l}\text { included } \\
0.59(0.537)\end{array}$ & $\begin{array}{l}\text { included } \\
2.43(1.326)\end{array}$ & $\begin{array}{l}\text { included } \\
1.39(1.191)\end{array}$ & $\begin{array}{l}\text { included } \\
1.19 \text { (1.443) }\end{array}$ & $\begin{array}{l}\text { included } \\
1.74(1.446)\end{array}$ & $\begin{array}{l}\text { included } \\
-0.95^{* * *} \\
(0.355)\end{array}$ & $\begin{array}{l}\text { included } \\
-0.90^{* *} \\
(0.366)\end{array}$ \\
\hline$N$ & 271 & 271 & 38 & 38 & 54 & 54 & 273 & 273 \\
\hline$F$ & 17.28 & 17.88 & - & - & - & - & 6.99 & 6.52 \\
\hline$R^{2}$ & 0.48 & 0.49 & 0.72 & 0.77 & 0.29 & 0.33 & 0.28 & 0.28 \\
\hline
\end{tabular}

H-H=High-High, H-L=High-Low, L-H = Low-High, L-L = Low-Low.

Standard errors in parentheses.

${ }^{*} \mathrm{p}<0.1 ;{ }^{* *} \mathrm{p}<0.05 ;{ }^{* * *} \mathrm{p}<0.01$ (two-tailed). 
integrated into innovations when firms are proactive in and are capable of integrating the knowledge, where integrating proactiveness is driven by technical problems and integrating capability is accumulated through innovation experience. Both technical problems and innovation experience are comprehensively reflected by internal technological orientations instead of unilaterally by breadth or depth. In addition, although breadth and depth work together, the effect of technological breadth appears to be more significant than that of technological depth.

Finally, this paper also makes an empirical contribution by expanding the use of technology positions to represent technology domains in R\&D collaboration research. The technology position is a more suitable unit than citations and patent classes, which are often used as measures of technological base and technological overlap (Rothaermel and Boeker, 2008; Diestre and Rajagopalan, 2012). The application of the technology position could eliminate the bias caused by the sequential interdependence and strategic motivations of inventors; this bias often occurs when using citations. Furthermore, the technology position provides more nuanced information than patent classes, which give relatively coarse information and ignore interdependencies between technological knowledge elements (Aharonson and Schilling, 2016).

\subsection{Implications for practitioners}

The findings of the present study have certain managerial implications. First, the results could help managers identify the technological orientations of their firms based on technological breadth and depth. This is informative for managers to elaborate the problems and competitive advantages of the knowledge structures of their firms and adopt suitable measures to leverage the breadth and depth of their firms' knowledge.

Second, the results can provide guidance for managers to decide on their firm's selection and adjustment of $R \& D$ collaboration strategies. Managers need to recognise that the impacts of technologically shortdistance collaborations and long-distance collaborations are different; thus, they can improve the innovation performance of firms effectively by adjusting their partner portfolio. In addition, managers should understand that collaborations may not necessarily lead to innovations, as a collaboration only provides access to the partner's knowledge, which is only the basic premise of knowledge integration. The newly accessed knowledge may be without value or may be difficult to be integrated with the internal knowledge of focal firms. Managers should have a clear understanding of the knowledge characteristics of their firms and those of their partners and select partners whose knowledge meets their needs and can be integrated according to their technological orientations.

The results of the present study also have implications for open innovation policy. Coccia (2012) showed that public R\&D expenditure can be a complement or substitute for private R\&D expenditure. Such a substitutive or complementary relationship may also exist between external knowledge accessed through collaborations and the internal knowledge of focal firms. When focal firms have sufficient attention and resources to integrate external knowledge, complementary effects may emerge; otherwise, 'crowding out' effects could emerge. Therefore, blindly encouraging open innovation may not contribute to innovation performance. A policy targeting for specific technologically oriented firms could help achieve the ideal balance between investment in internal knowledge integration and investment in external knowledge integration.

\subsection{Limitations and future work}

Despite the above contributions, this paper has certain limitations, which also offer avenues for future research. First, the effects of knowledge distance on the focal firms' innovation performance were solely analysed from the perspective of focal firms. The premise of the theoretical framework is that partners would like to share their knowledge with focal firms once R\&D collaboration has successfully formed.
However, research has pointed out that firms engaged in collaborations may strive to prevent their knowledge from leaking out under specific circumstances (Gulati and Singh, 1998; Oxley and Sampson, 2004), which has been omitted in this paper. Future studies could combine this cost consideration from the partner and the value-creating consideration from focal firms to address this question.

Second, the empirical analysis in this paper has a number of limitations. Collaborations were identified based on joint patents. However, co-publications and publicly supported collaborative R\&D projects are also important databases for identifying cooperative relationships between organisations (Fritsch et al., 2020). Future studies, especially for industries where patent applications are not active, should apply a more comprehensive data system to yield more complete alliance networks. In addition, researchers could analyse the distribution of the overlapping technology positions within the technology landscapes of focal firms and their partners to more accurately distinguish the distances between the two parties. Finally, the developed theory was tested using data from the new-energy vehicle industry only. We encourage researchers to conduct future studies in other industries to validate our findings.

\section{Funding}

This research was supported by the National Natural Science Foundation of China [grant numbers 71673037 and 72074040].

\section{Acknowledgements}

We thank Bart Van Looy and Hui Tan for their constructive suggestions. We also wish to acknowledge the two anonymous referees for their insightful guidance.

\section{References}

Aharonson, B.S., Schilling, M.A., 2016. Mapping the technological landscape: measuring technology distance, technological footprints, and technology evolution. Res. Pol. 45, 81-96.

Ahuja, G., 2000a. Collaboration networks, structural holes, and Innovation : a longitudinal study. Adm. Sci. Q. 45, 425-455.

Ahuja, G., 2000b. The duality of collaboration: inducements and opportunities in the formation of interfirm linkages. Strat. Manag. J. 21 (3), 317-343.

Ahuja, G., Soda, G., Zaheer, A., 2012. The genesis and dynamics of organizational networks. Organ. Sci. 23 (2), 434-448.

Argyres, N., Rios, L.A., Silverman, B.S., 2020. Organizational change and the dynamics of innovation: formal R\&D structure and intrafirm inventor networks. Strat. Manag. J. 41 (11), 2015-2049.

Belderbos, R., Carree, M., Lokshin, B., 2004. Cooperative R\&D and firm performance. Res. Pol. 33 (10), 1477-1492.

Berchicci, L., 2013. Towards an open R\&D system: internal R\&D investment, external knowledge acquisition and innovative performance. Res. Pol. 42 (1), 117-127.

Bogers, M., Chesbrough, H., Heaton, S., et al., 2019. Strategic management of open innovation: a dynamic capabilities perspective. Calif. Manag. Rev. 62 (1), 77-94.

Boh, W.F., Evaristo, R., Ouderkirk, A., 2014. Balancing breadth and depth of expertise for innovation: a 3M story. Res. Policy 43, 349-366.

Bresman, H., Birkinshaw, J., Nobel, R., 1999. Knowledge transfer in international acquisitions. J. Int. Bus. Stud. 30, 439-462.

Buckley, P.J., Glaister, K.W., Klijn, E., Tan, H., 2009. Knowledge accession and knowledge acquisition in strategic alliances: the impact of supplementary and complementary dimensions. Br. J. Manag. 20 (4), 598-609.

Caner, T., Cohen, S.K., Pil, F., 2017. Firm heterogeneity in complex problem solving: a knowledge-based look at invention. Strat. Manag. J. 38, 1791-1811.

Caner, T., Tyler, B.B., 2015. The effects of knowledge depth and scope on the relationship between R\&D alliances and new product development. J. Prod. Innovat. Manag. 32, $808-824$.

Capaldo, A., Messeni, A., 2015. Origins of knowledge and innovation in R \& D alliances : a contingency approach. Technol. Anal. Strat. Manag. 27, 461-483.

Carnabuci, G., Operti, E., 2013. Where do firms' recombinant capabilities come from? Intraorganizational networks, knowledge, and firms' ability to innovate through technological recombination. Strat. Manag. J. 34, 1591-1613.

Chesbrough, H., 2006. Open Business Models: How to Thrive in the New Innovation Landscape, MA. Harvard Business Press, Boston.

Coccia, M., 2017. Sources of technological innovation: radical and incremental innovation problem-driven to support competitive advantage of firms. Technol. Anal. Strat. Manag. 29 (9), 1048-1061.

Coccia, M., 2012. Political economy of R\&D to support the modern competitiveness of nations and determinants of economic optimization and inertia. Technovation 32 (6), 370-379. 
Cohen, W.M., Levinthal, D.A., 1990. Absorptive Capacity : a new perspective on and innovation learning. Adm. Sci. Q. 35, 128-152.

Cusumano, M.A., Kahl, S.j., Suarez, F.F., 2014. Technological overlap, technological capabilities, and resource recombination in technological acquisitions. Strat. Manag. J. $35,48-67$.

Cui, A.S., O'Connor, G., 2012. Alliance portfolio resource diversity and firm innovation. J. Mark. 76 (4), 24-43.

Dawid, H., Hellmann, T., 2020. R\&D investments under endogenous cluster formation. J. Econ. Behav. Organ. 174, 253-283.

Denrell, J., March, J.G., 2001. Adaptation as information restriction: the hot stove effect. Organ. Sci. 12 (5), 523-538.

Diestre, L., Rajagopalan, N., 2012. Are all 'sharks' dangerous? New biotechnology ventures and partner selection in R\&D alliances. Strat. Manag. J. 33, 1115-1134.

Dothan, A., Lavie, D., 2016. Resource reconfiguration: learning from performance feedback. In: Resource Redeployment and Corporate Strategy. Emerald Group Publishing Ltd., pp. 319-369

Eggers, J.P., Kaul, A., 2018. Motivation and Ability ? A behavioral perspective on the pursuit of radical invention in multi-technology incumbents. Acad. Manag. J. 61, 67-93.

Eggers, J.P., Suh, J.H., 2019. Experience and behavior: how negative feedback in new versus experienced domains affects firm action and subsequent performance. Acad. Manag. J. 62 (2), 309-334.

Enkel, E., Gassmann, O., Chesbrough, H., 2009. Open R\&D and open innovation: exploring the phenomenon. R D Manag. 39 (4), 311-316.

Farazi, M.S., Gopalakrishnan, S., Perez-Luño, A., 2019. Depth and breadth of knowledge and the governance of technology alliances. J. Eng. Technol. Manag. 54, 28-40.

Fleming, L., 2001. Recombinant uncertainty in technological search. Manag. Sci. 47, 117-132.

Fleming, L., Sorenson, O., 2001. Technology as a complex adaptive system: evidence from patent data. Res. Pol. 30, 1019-1039.

Fritsch, M., Titze, M., Piontek, M., 2020. Identifying cooperation for innovation-a comparison of data sources. Ind. Innovat. 27 (6), 630-659.

Giura, S.I., Kumar, S., 2019. The impact of alliances on knowledge growth within firms. IEEE Trans. Eng. Manag.

Ghosh, A., Martin, X., Pennings, J.M., Wezel, C.F., 2014. Ambition is nothing without focus: compensating for negative transfer of experience in R\&D. Organ. Sci. 25 (2), 572-590.

Grant, R.M., 1996a. Prospering in dynamically-competitive environments: organizational capability as knowledge integration. Organ. Sci. 7, 375-387.

Grant, R.M., 1996b. Toward a knowledge-based theory of the firm. Strat. Manag. J. 17, 109-122.

Grant, R.M., Baden-Fuller, C., 2004. A knowledge accessing theory of strategic alliances. J. Manag. Stud. 41, 61-84.

Greve, H.R., 2003. A behavioral theory of R\&D expenditures and innovations: evidence from shipbuilding. Acad. Manag. J. 46 (6), 685-702.

Gulati, R., Singh, H., 1998. The architecture of cooperation: managing coordination cost and appropriation concerns in strategic alliances. Adm. Sci. Q. 43 (4), 781-814.

Hagedoorn, J., 2002. Inter-firm R\&D partnerships: an overview of major trends and patterns since 1960. Res. Pol. 31, 477-492.

Hagedoorn, J., Lokshin, B., Zobel, A.K., 2018. Partner type diversity in alliance portfolios: multiple dimensions, boundary conditions and firm innovation performance. J. Manag. Stud. 55, 809-836.

Helfat, C.E., 1994. Evolutionary trajectories in petroleum firm R\&D. Manag. Sci. 40, $1720-1747$.

Kang, K.H., Kang, J., 2010. Does partner type matter in R\&D collaboration for product innovation? Technol. Anal. Strat. Manag. 22 (8), 945-959.

Karbowski, A., Prokop, J., 2020. The impact of patents and R\&D cooperation on R\&D investments in a differentiated goods industry. S. East Eur. J. Econ. Bus. 15 (1), 122-133.

Katila, R., Ahuja, G., 2002. Something old, something new: a longitudinal study of search behavior and new product introduction. Acad. Manag. J. 45, 1183-1194.

Kavusan, K., Noorderhaven, N.G., Duysters, G.M., 2016. Knowledge acquisition and complementary specialization in alliances: the impact of technological overlap and alliance experience. Res. Pol. 45, 2153-2165.

Kim, J., Lee, C.Y., Cho, Y., 2016. Technological diversification, core-technology competence, and firm growth. Res. Pol. 45, 113-124.

Kok, H., Faems, D., de Faria, P., 2020. Ties that matter: the impact of alliance partner knowledge recombination novelty on knowledge utilization in R\&D alliances. Res. Pol. 49 (7), 104011.
Kratzer, J., Meissner, D., Rould, V., 2017. Open innovation and company culture: internal openness makes the difference. Technol. Forecast. Soc. Change 119, $128-138$.

Lane, P.J., Lubatkin, M., 1998. Relative absorptive capacity and interorganizational learning. Strat. Manag. J. 19 (5), 461-477.

Leiponen, A., Helfat, C.E., 2010. Innovation objectives, knowledge sources, and the benefits of breadth. Strat. Manag. J. 31 (2), 224-236.

Lin, B.W., Wu, C.H., 2010. How does knowledge depth moderate the performance of internal and external knowledge sourcing strategies? Technovation 30, 582-589.

Lopes, A.P.V.B.V., de Carvalho, M.M., 2018. Evolution of the open innovation paradigm: towards a contingent conceptual model. Technol. Forecast. Soc. Change 132, 284-298.

Maietta, O.W., 2015. Determinants of university-firm R\&D collaboration and its impact on innovation: a perspective from a low-tech industry. Res. Pol. 44 (7), 1341-1359.

Miller, D.J., Fern, M.J., Cardinal, L.B., 2007. The use of knowledge for technological innovation within diversified firms. Acad. Manag. J. 50 (2), 307-325.

Mowery, D.C., Oxley, J.E., Silverman, B.S., 1996. Strategic alliances and interfirm knowledge transfer. Strat. Manag. J. 17, 77-91.

Oxley, J.E., Sampson, R.C., 2004. The scope and governance of international R\&D alliances. Strat. Manag. J. 25 (8-9), 723-749.

Pisano, G., Teece, D., 1989. Collaborative arrangements and global technology strategy: some evidence from the telecommunications equipment industry. In: Rosenblum, R. (Ed.), Research onTechnological Innovation, Management and Policy, vol. 4. JAI Press, Greenwich, CT, pp. 227-256.

Prashantham, S., Zhou, A.J., Dhanaraj, C., 2020. Depth vs. Breadth: network strategy in emerging markets. Manag. Organ. Rev. 16 (2), 229-260.

Rosenkopf, L., Almeida, P., 2003. Overcoming local search through alliances and mobility. Manag. Sci. 49, 751-766.

Rothaermel, F.T., Hess, A.M., 2007. Building dynamic capabilities: innovation driven by individual-, firm-, and network-level effects. Organ. Sci. 18, 898-921.

Rothaermel, F.T., Boeker, W., 2008. Old technology meets new technology: complementarities, similarities, and alliance formation. Strat. Manag. J. 29, 47-77.

Sampson, R.C., 2007. R\&D alliances and firm performance: the impact of technological diversity and alliance organization on innovation. Acad. Manag. J. 50 (2), 364-386.

Schildt, H., Keil, T., Maula, M., 2012. The temporal effects of relative and firm-level absorptive capacity on interorganizational learning. Strat. Manag. J. 33, 1154-1173.

Subramanian, A.M., Bo, W., Kah-Hin, C., 2018. The role of knowledge base homogeneity in learning from strategic alliances. Res. Pol. 47 (1), 158-168.

Tversky, A., Kahneman, D., 1979. Prospect theory: an analysis of decision under risk. Econometrica 47 (2), 263-291.

Van Beers, C., Zand, F., 2014. R\&D cooperation, partner diversity, and innovation performance: an empirical analysis. J. Prod. Innovat. Manag. 31 (2), 292-312.

Vanhaverbeke, W., Vermeersch, I., De Zutter, S., 2012. Open innovation in SME's: how can small companies and start-ups benefit from open innovation strategies? Flanders DC. http://hdl.handle.net/20.500.12127/4048.

Vom Stein, N., Sick, N., Leker, J., 2015. How to measure technological distance in collaborations - the case of electric mobility. Technol. Forecast. Soc. Change 97, 154-167.

Wang, C., Hu, Q., 2020. Knowledge sharing in supply chain networks: effects of collaborative innovation activities and capability on innovation performance. Technovation 94, 102010.

Wang, J., 2016. Knowledge creation in collaboration networks: effects of tie configuration. Res. Pol. 45 (1), 68-80.

Wiklund, J., Shepherd, D., 2003. Knowledge-based resources, entrepreneurial orientation, and the performance of small and medium-sized businesses. Strat. Manag. J. 24 (13), 1307-1314.

Yayavaram, S., Ahuja, G., 2008. Decomposability in knowledge structures and its impact on the usefulness of inventions and knowledge-base malleability. Adm. Sci. Q. 53, 333-362.

Yayavaram, S., Srivastava, M.K., Sarkar, M., 2018. Role of search for domain knowledge and architectural knowledge in alliance partner selection. Strat. Manag. J. 39, 2277-2302.

Zahra, S.A., George, G., 2002. Absorptive capacity: a review, reconceptualization, and extension. Acad. Manag. Rev. 27, 185-203.

Zhang, S., Zhang, N., Zhu, S., et al., 2020. A foot in two camps or your undivided attention? The impact of intra-and inter-community collaboration on firm innovation performance. Technol. Anal. Strat. Manag. 32, 753-768.

Zobel, A.K., 2017. Benefiting from open innovation: a multidimensional model of absorptive capacity. J. Prod. Innovat. Manag. 34 (3), 269-288. 